\title{
Optimization of cellulase production by Penicillium sp.
}

\author{
H. N. Prasanna ${ }^{1}$ G. Ramanjaneyulu ${ }^{1}$ B. Rajasekhar Reddy ${ }^{1}$
}

Received: 18 March 2016/ Accepted: 1 August 2016/Published online: 9 August 2016

(c) The Author(s) 2016. This article is published with open access at Springerlink.com

\begin{abstract}
The production of cellulolytic enzymes ( $\beta$-exoglucanase, $\beta$-endoglucanase and $\beta$-glucosidase) by Penicillium sp. on three different media in liquid shake culture conditions was compared. The organism exhibited relatively highest activity of endoglucanase among three enzymes measured at 7-day interval during the course of its growth on Czapek-Dox medium supplemented with $0.5 \%$ (w/v) cellulose. Cellulose at $0.5 \%$, lactose at $0.5 \%$, sawdust at $0.5 \%$, yeast extract at $0.2 \%$ as a nitrogen source, $\mathrm{pH} 5.0$ and $30{ }^{\circ} \mathrm{C}$ temperature were found to be optimal for growth and cellulase production by Penicillium sp. Yields of Fpase, CMCase and $\beta$-glucosidase, attained on optimized medium with Penicillium sp. were 8.7, 25 and $9.52 \mathrm{U} / \mathrm{ml}$, respectively with increment of 9.2, 5.9 and 43.8-folds over titers of the respective enzyme on unoptimised medium. Cellulase of the fungal culture with the ratio of $\beta$-glucosidase to Fpase greater than one will hold potential for biotechnological applications.
\end{abstract}

Keywords $\beta$-Glucosidase - Endoglucanase - Exoglucanase - Nutrients - Optimization P Penicillium sp.

\section{Introduction}

Energy and environment are the essential aspects of human life almost all over the world. The conventional sources that meet the demand on energy needs will not last long and therefore non-conventional alternative and renewable

B. Rajasekhar Reddy

rajasekharb64@gmail.com

1 Department of Microbiology, Sri Krishnadevaraya University, Anantapuramu, Andhra Pradesh, India sources are to be exploited for this purpose (Tuo 2013; Zhao et al. 2016). This planet is threatened due to environmental pollution in recent years as a result of disposal of solid and liquid wastes rich in organics. Solid and liquid waste rich in organics can be considered for generation of energy by biotechnological means (Koneswaran and Nierenberg 2008; Ashfaq and Khatoon 2013; Lytle 2016). Utilization of solid and liquid wastes will provide twin benefits saving the environment from polluted menace and generating energy (Hinds 2015; Jeihanipour and Bashiri 2015).

Cellulose constitutes bulk of the plant cell wall materials and is the most abundant and renewable non-fossil carbon source on earth ( $\mathrm{Li}$ et al. 2009). Cellulose occurs in municipal wastes, forest products, agriculture, fruits and vegetables. Cellulose has enormous potential as a renewable source of energy (Coral et al. 2002) and a number of microorganisms use it as a carbon source. Major constraints in enzymatic hydrolysis of cellulosic materials for the production of fermentation sugar are low productivity and the high cost of cellulases (Lee et al. 2010). This cellulose polymer could be converted into simple sugars in saccharification process by cellulase enzymes derived from microbial system. Cellulase is a complex of three types of enzymatic complexes namely, cellobiohydrolases (EC 3.2.1.91), endoglucanases or CMCases (EC 3.2.1.4) and $\beta$ glucosidases (EC 3.2.1.21), acting synergistically to convert complex carbohydrates present in lingocellulosic (LC) biomass into glucose (Iqbal et al. 2011). The simple sugar can then be utilised by other organisms to produce a variety of fermentation chemicals (alcohols-ethanol, butanol, solvents-acetone or 2,3-butanediol etc.) (Gadgil et al. 1995; Hoshino et al. 1997; Van Wyk 2001; Lee et al. 2008; Sanil et al. 2015). In addition to their importance in saccharification, cellulases are currently being used in several other 
industrial processes-starch processing, animal feed applications, grain alcohol fermentation, malting and brewing, extraction of fruit and vegetable juices, paper and pulp industry, textile industry and waste water treatment (Bhat and Bhat 1997; Bhat 2000; Penttila et al. 2004; Koomnok 2005; Kuhad et al. 2011; Yano et al. 2012; Adrio and Demain 2014). In view of biotechnological importance, microbial production of cellulases continues to be a subject of interest and to attract a great deal of attention from cross sections of scientists. Secretion of cellulolytic enzymes by different organisms in nature needs to be continuously monitored. Trichoderma species, in particular, reesei received more attention for the production of cellulolytic enzymes but $\beta$-glucosidase activity was very low in cellulase enzymes of Trichoderma reesei (Peterson and Nevalainen 2012). Continuous search for the production of cellulase with high $\beta$-glucosidase activity has been bringing other organisms including Penicillium species into lime light (Gusakov and Sinitsyn 2012). The present investigation reported secretion of cellulolytic enzymes by a local and potential isolate Penicillium sp. grown on different nutrient sources in submerged fermentation in a laboratory study.

\section{Materials and methods}

\section{Media}

Composition of three media (basal medium, minimal medium and Czapek-Dox medium) used in this study is as follows and is expressed in $\mathrm{g} / \mathrm{L}$. Basal medium contained ingredients-yeast extract $10, \mathrm{NaCl} 2, \mathrm{CaCl}_{2} 0.2, \mathrm{KH}_{2} \mathrm{PO}_{4} 2$, $\mathrm{FeCl}_{2}$ 0.01, $\mathrm{MgSO}_{4}$ 1.7, $\mathrm{NH}_{4} \mathrm{Cl}$ 2, distilled water 1000. Minimal medium: $\mathrm{KH}_{2} \mathrm{PO}_{4} 0.04, \mathrm{~K}_{2} \mathrm{HPO}_{4} 0.1, \mathrm{Na}_{2} \mathrm{HPO}_{4}$ $0.10, \mathrm{NH}_{4} \mathrm{SO}_{4} 0.008, \mathrm{MgSO}_{4} 0.02,\left(\mathrm{NH}_{4}\right)_{2} \mathrm{SO}_{4} 0.04, \mathrm{CaCl}_{2}$ 0.027, distilled water 1000 and Czapek-Dox medium: sucrose 30, $\mathrm{NaNO}_{3} 2, \mathrm{~K}_{2} \mathrm{HPO}_{4} 1, \mathrm{MgSO}_{4} 0.05, \mathrm{KCl} 0.5$, $\mathrm{FeSO}_{4}$ 0.01, distilled water 1000. $\mathrm{pH}$ of all the three media was adjusted to 7.0.

\section{Culture conditions and enzyme production}

Penicillium sp., isolated from soil polluted with effluents discharged by a cotton ginning industry (Narasimha et al. 1999), was used in this study. Sterilised $50 \mathrm{ml}$ of each of the three different media, (minimal, basal and Czapek-Dox) amended with $0.5 \%$ cellulose as carbon source was distributed into sterile $250 \mathrm{ml}$ Erlenmeyer flask. Meanwhile, the spore suspension was prepared in sterile distilled water from 6-day-old culture of Penicillium sp. grown on Potato-Dextrose Agar (PDA) slants. The flasks were inoculated with a density of $2 \times 10^{6}$ spores and incubated at $28^{\circ} \mathrm{C}$ on a rotary shaker (140 rpm). As the maximal cellulolytic activity with fungal cultures was observed on the 7th day of incubation in the preliminary study (Prasanna 2003), flasks were withdrawn only on the 7 day of incubation and filtered through Whatman No. 1 filter paper to separate mycelial mat and culture filtrate.

Fungal growth was expressed in terms of dry weight (mg/flask) of mycelial mat after drying at $70{ }^{\circ} \mathrm{C}$ in an oven until constant weight. The content of soluble protein in the culture filtrate was estimated according to the method of Lowry et al. (1951) with bovine serum albumin as a standard. Total activity of cellulase complex and/or individual component enzyme activities in the culture filtrate were determined as per procedures described below. In view of maximum growth and cellulase activity on the Czapek-Dox medium at 7 th day interval, subsequent experiments were carried out on Czapek-Dox medium, to find out the influence of supplementation of different carbon, nitrogen lignocellulose sources, temperature, $\mathrm{pH}$ and surfactants on growth, secretion of extracellular protein content and cellulase production by Penicillium sp. at only 7 th day incubation.

\section{Enzyme assays}

\section{Fpase assay}

Filter paper activity (FPA) for total cellulase activity in the cultural filtrate was determined according to the method of Mandels and Weber (1969). Aliquots of appropriately diluted culture filtrate as enzyme source was added to Whatman No. 1 filter paper strip $(1 \times 6 \mathrm{~cm}, 50 \mathrm{mg})$ immersed in $1 \mathrm{ml}$ of $0.05 \mathrm{M}$ sodium citrate buffer of $\mathrm{pH}$ 4.8. After incubation at $50{ }^{\circ} \mathrm{C}$ for $1 \mathrm{~h}$, the reducing sugar released was estimated by Dinitrosalicylic acid (DNS) method (Miller 1959). One unit of filter paper (FPU) activity was defined as the amount of enzyme releasing $1 \mu \mathrm{mol}$ of reducing sugar from filter paper per $\mathrm{ml}$ per minute.

\section{CMCase assay}

Endoglucanase activity carboxymethylcellulase (CMCase) was measured as described previously (Ghosh 1987) using a reaction mixture containing $1 \mathrm{ml}$ of $1 \%$ carboxymethyl cellulose (CMC) in $0.2 \mathrm{M}$ acetate buffer ( $\mathrm{pH} 5.0)$ and aliquots of suitably diluted filtrate. The reaction mixture was incubated at $50{ }^{\circ} \mathrm{C}$ for 30 minutes and the reducing sugar produced was determined by DNS method. One unit (IU) of endoglucanase activity was defined as the amount of enzyme releasing $1 \mu \mathrm{mol}$ of reducing sugar per min. 


\section{$\beta$-Glucosidase assay}

$\beta$-Glucosidase activity was assayed by the method of Herr (1979). $\beta$-glucosidase activity was measured in $1 \mathrm{ml}$ of $5 \mathrm{mM} p$-nitropheny1- $\beta$-D-glucopyranoside (PNPG) in $0.2 \mathrm{M}$ acetate buffer ( $\mathrm{pH}$ 5.0) and aliquots of appropriately diluted culture filtrate and incubated at $50{ }^{\circ} \mathrm{C}$ for $30 \mathrm{~min}$. The reaction was terminated by addition of $4 \mathrm{ml}$ of $0.05 \mathrm{M}$ $\mathrm{NaOH}-$ glycine buffer ( $\mathrm{pH}$ 10.6) solution and the released $p$-nitrophenol was read at $405 \mathrm{~nm}$ and the activity was expressed in terms of liberation of $p$-nitrophenol from $p$ nitrophenyl- $\beta$-D-glucopyranoside (PNPG). One unit of the enzyme activity was defined as the amount of enzyme producing $1 \mu \mathrm{mol}$ of $p$-nitrophenol per min.

\section{Results and discussion}

Penicillium sp. was cultured on three liquid media (minimal, basal and Czapek-Dox) amended with $0.5 \%$ cellulose at $28{ }^{\circ} \mathrm{C}$ under shaking conditions. Growth, extracellular protein content and total cellulolytic activity in the culture filtrate were monitored on 7th-day incubation and are presented in the Table 1. Czapek-Dox medium supported the maximum growth of Penicillium sp. when compared to basal and minimal media. The maximal secretion of extracellular protein content was derived from basal medium followed by Czapek-Dox medium and minimal medium; Penicillium sp. grown in Czapek-Dox medium yielded highest production of all three enzyme components of cellulase with $0.94,4.21$ and $0.21 \mathrm{U} / \mathrm{ml}$ filter paperase, Carboxymethyl cellulase and $\beta$-glucosidase, respectively. FPase activity was not detected in culture filtrate of basal medium but activities of CMCase and $\beta$-glucosidase to the titer of 2.88 and $0.19 \mathrm{U} / \mathrm{m} 1$ were observed. Minimal medium induced least activity of $\beta$-glucosidase, but no
FPase and CMCase was detected. Cellulase activity was observed upon growth of Penicilium sp. on only mineral medium supplemented with avicel, rice straw, and CMCellulose but not on potato dextrose broth supplemented with the same cellulosic materials and reached maximum level with CMCase titers of 6-7 U/ml in 24 days incubation (Picart et al. 2007). Species of Penicillium (wild type) such as pinophilum (Jorgensen et al. 2005) decumbens (Sun et al. 2008) and xanthinellum (Singhvi et al. 2011) secreted about 1-3 U/ml of Fpase and $\beta$-glucosidase on cellulosic materials in submerged fermentation $(\mathrm{SmF})$.

The major components of production medium like carbon and nitrogen sources and physical parameters like temperature, $\mathrm{pH}$ and incubation time were found to be critically affecting the cellulase production hence need to be optimized for every isolate (Polyanna et al. 2011). Influence of supplementation of different soluble carbon sources $(0.5 \%)$ to Czapek-Dox medium on cellulase production by Penicillium sp. was examined and is presented in Table 2. Among carbon sources, lactose was the best source followed by carboxymethyl cellulose and galactose for cellulase production, biomass and secretion of extracellular protein by Penicillium sp. Activities of even other individual components of cellulase, such as filter paperase and $\beta$-glucosidase were also highest in culture filtrate of Penicillium sp. grown in the presence of lactose. This study substantiates the work of Kathiresan and Manivannan (2006) and Devanathan et al. (2007) who demonstrated lactose as best inducer of Aspergillus sp. Muthuvelayudham and Viruthagiri (2006) reported maximum growth and cellulase enzyme production by $T$. reesei $\mathrm{C} 5$ with provision of lactose as sole carbon source. Similarly, lactose present in cheese and whey induced the cellulase biosynthesis in Trichoderma reesei MCG 80 (Sternberg and Mandels 1979; Allen and Andreotti 1982). The presence of sorbitol at $0.5 \%$ level along with cellulose supported maximum

Table 1 Growth, protein secretion and cellulase production by Penicillium sp. on different media

\begin{tabular}{llllll}
\hline Medium & $\begin{array}{l}\text { Dry weight of mycelial } \\
\text { mat (mg/flask) }\end{array}$ & $\begin{array}{l}\text { Protein content } \\
(\mathrm{mg} / \mathrm{ml})\end{array}$ & \multicolumn{2}{l}{ Cellulase } \\
\cline { 4 - 6 } & 410 & 2.69 & ${ }^{\mathrm{a}}$ FPase (FPU/ml) & ${ }^{\mathrm{b} C M C a s e ~(U / m l)}$ & ${ }^{\mathrm{c} B-g l u c o s i d a s e}(\mathrm{U} / \mathrm{ml})$ \\
\hline Basal & 450 & 1.70 & - nd- & 2.88 & 0.19 \\
Czapeck dox & 260 & 0.60 & 0.94 & 4.21 & 0.21 \\
Minimal & 260 & - nd- & -nd- & 0.03 \\
\hline
\end{tabular}

Values represented in the table are averages of results of two experiments

-nd- not detected

${ }^{\text {a }}$ Filter paperase (FPase) is expressed in terms of filter paper units. One unit is the amount of enzyme in the culture filtrate releasing $\mu$ mol of reducing sugar from filter paper per min

${ }^{\mathrm{b}}$ Carboxymethyl cellulase (CMCase) is expressed in terms of units. One unit is the amount of enzyme releasing $1 \mu$ mol of reducing sugar from carboxymethyl cellulose per min

${ }^{c}$ One unit of $\beta$-glucosidase activity is defined as the amount of enzyme liberating $1 \mu$ mol of $p$-nitrophenol per min 
Table 2 Effect of supplementation of carbon source on cellulase production by Penicillium sp.

\begin{tabular}{|c|c|c|c|c|c|}
\hline \multirow[t]{2}{*}{ Carbon source } & \multirow{2}{*}{$\begin{array}{l}\text { Dry weight of mycelial } \\
\text { mat (mg/flask) }\end{array}$} & \multirow{2}{*}{$\begin{array}{l}\text { Protein content } \\
(\mathrm{mg} / \mathrm{ml})\end{array}$} & \multicolumn{3}{|l|}{ Cellulase } \\
\hline & & & ${ }^{\mathrm{a}}$ FPase (FPU/ml) & ${ }^{\mathrm{b}} \mathrm{CMCase}(\mathrm{U} / \mathrm{ml})$ & ${ }^{\mathrm{c}} \mathrm{B}$-glucosidase $(\mathrm{U} / \mathrm{ml})$ \\
\hline Sarbose & 420 & 2.17 & 3.53 & 8.23 & 1.16 \\
\hline Maltose & 369 & 2.37 & 8.24 & 10.35 & 1.67 \\
\hline Sucrose & 275 & 2.05 & 5.40 & 13.18 & 1.87 \\
\hline Lactose & 497 & 2.78 & 9.12 & 24.70 & 2.32 \\
\hline Dextrose & 412 & 2.45 & 5.18 & 10.35 & 1.04 \\
\hline Galactose & 445 & 2.12 & 6.82 & 14.35 & 2.01 \\
\hline Cellobiose & 338 & 1.92 & -nd- & 14.12 & 1.46 \\
\hline CMC & 529 & 1.97 & 4.71 & 18.82 & 1.95 \\
\hline Control & 378 & 2.28 & 5.99 & 11.99 & 1.98 \\
\hline
\end{tabular}

Values represented in the table are averages of results of two experiments

-nd- not detected

${ }^{a}$ Filter paperase (FPase) is expressed in terms of filter paper units. One unit is the amount of enzyme in the culture filtrate releasing $\mu$ mole of reducing sugar from filter paper per min

${ }^{\mathrm{b}}$ Carboxymethyl cellulase (CMCase) is expressed in terms of units. One unit is the amount of enzyme releasing $1 \mu$ mol of reducing sugar from carboxymethyl cellulose per min

${ }^{c}$ One unit of $\beta$-glucosidase activity is defined as the amount of enzyme liberating $1 \mu$ mol of $p$-nitrophenol per min

production of FPase by Penicillium echinulatum on 7th day of incubation in SmF (Ritter et al. 2013). The low production of enzyme components of cellulase by Penicillium sp. on glucose supplemented medium was observed in the present study. Similarly, no cellulolytic activity was observed in culture filtrate of Penicillium sp. grown on Potato Dextrose Broth (Picart et al. 2007). Gautam et al. (2010) studied the production of cellulase (filter paper activity, $\beta$-endoglucanase and $\beta$-glucosidase) by Aspergillus niger on three different carbon sources such as glucose, cellulose and waste cellulosic material. Glucose containing media gave the highest mycelial weight of $1.294 \mathrm{mg} / \mathrm{flask}$. Maximum cellulase enzyme activity (filter paper activity, endoglucanase and $\beta$-glucosidase) were obtained from the culture containing cellulose. Low levels of production of cellulase enzymes by organisms in media with glucose even in the present study could be attributed to repression of synthesis of the cellulase enzymes related to catabolism of alternate carbon such as cellulose (Ruijter and Visser 1997; Peterson and Nevalainen 2012; Gusakov and Sinitsyn 2012).

Cellulase production on different nitrogen sources by Penicillium sp. is compared (Table 3). Among all these nitrogen sources $(0.2 \%)$ tested in this study, yeast extract is the best source followed by peptone for production of cellulolytic enzymes. Biomass, extracellular protein content yielded by Penicillium sp. were higher on organic nitrogen than on inorganic nitrogen and were correlated to cellulase production. Peptone enhanced CMCase activity in
Gliocladium virens, and high $\beta$-glucosidase activity in $A$. niger and A. terreus (Gomes et al. 1989). Similarly, enhancement of cellulase production in Volariella displasia occurred in the presence of peptone (Guptha et al. 1996). The addition of $2 \% \mathrm{w} / \mathrm{w}$ urea to soy hull in solid state fermentation by Phanerochaete chrysosporium enhanced the production of CM-cellulase and filter paperase (Jha et al. 1995). Incubation of urea in medium at high concentration of $0.525 \mathrm{~g} / 1$ resulted in maximal production of cellulase by Penicillium echinulatum in SmF (dos Reis et al. 2015). High yields of protein content was attained by cultivation of Chrysosporium sp. and Thielavia sp. on Czapek medium containing beet pulp as carbon, and urea as nitrogen source (Bilai et al. 1985). Various researchers have shown that different organic and inorganic nitrogen sources such as yeast extract (Ganguly and Mukherjee 1995); soya meal (Gomes et al. 2000) and corn steep liquor (Hayward et al. 2000) influenced the cellulase production. Organic nitrogen substances had varied effects on production of individual enzyme components in cellulase system by Polyporous sp. (Nigam and Prabhu 1991). Peptone was found to be the most promising and effective nitrogen source for cellulase production by Penicillium waksmanii F10-2 (Han et al. 2009). Supplementation of $\mathrm{NH}_{4} \mathrm{NO}_{3}$ as the nitrogen source had the highest impact on cellulase production (Singhania et al. 2006).

High levels of CMCase $(50-60 \mathrm{U} / \mathrm{ml})$ and filter paperase ( $3 \mathrm{U} / \mathrm{ml}$ ) along with maximum extracellular protein content were attained with the addition of corn steep liquor (Farid 
Table 3 Effect of supplementation of nitrogen source on cellulase production by Penicillium sp.

\begin{tabular}{llllll}
\hline Nitrogen source & $\begin{array}{l}\text { Dry weight of mycelial } \\
\text { mat (mg/flask) }\end{array}$ & $\begin{array}{l}\text { Protein content } \\
(\mathrm{mg} / \mathrm{ml})\end{array}$ & \multicolumn{2}{l}{ Cellulase } \\
\cline { 3 - 5 } & & & ${ }^{\mathrm{a}}$ FPase (FPU/ml) & ${ }^{\mathrm{b} C M C a s e}(\mathrm{U} / \mathrm{ml})$ & ${ }^{\mathrm{c}} \mathrm{B}-\mathrm{glucosidase}(\mathrm{U} / \mathrm{ml})$ \\
\hline $\mathrm{NH}_{4} \mathrm{Cl}$ & 150 & 1.08 & - nd- & 0.70 & 0.34 \\
$\left(\mathrm{NH}_{4}\right)_{2} \mathrm{SO}_{4}$ & 112 & 0.97 & - nd- & - nd- & 0.12 \\
$\mathrm{KNO}_{3}$ & 165 & 1.00 & - nd- & 1.20 & 1.20 \\
Peptone & 475 & 2.07 & 1.35 & 8.64 & 3.68 \\
Urea & 405 & 1.38 & 0.15 & 3.36 & 1.74 \\
Yeast extract & 490 & 2.38 & 2.70 & 12.00 & 11.35 \\
Control & 378 & 2.28 & 5.99 & 11.99 & 1.98 \\
\hline
\end{tabular}

Values represented in the table are averages of results of two experiments

-nd- not detected

${ }^{\text {a }}$ Filter paperase (FPase) is expressed in terms of filter paper units. One unit is the amount of enzyme in the culture filtrate releasing $\mu$ mol of reducing sugar from filter paper per min

${ }^{\mathrm{b}}$ Carboxymethyl cellulase (CMCase) is expressed in terms of units. One unit is the amount of enzyme releasing $1 \mu$ mol of reducing sugar from carboxymethyl cellulose per min

${ }^{c}$ One unit of $\beta$-glucosidase activity is defined as the amount of enzyme liberating $1 \mu$ mol of $p$-nitrophenol per min

and El-Shaheed 1993). In addition, whey at low levels $0.2 \%$ to the medium of cellulose and corn steep liquor stimulated cellulase production but higher concentrations inhibited cellulase production. The addition of skim milk powder at $0.2 \%$ enhanced activities of exoglucanase and endoglucanase by Trichoderma reesei but had no influence on $\beta$ glucosidase activity (Patil et al. 1995). Organic forms of nitrogen such as yeast extract and peptone served as better nitrogen sources for production of cellulase in comparison to inorganic nitrogen forms in the present study.

The bioconversion of agro waste based lignocellulosic material to energy has gained much interest during the recent past. Low cost of enzyme production improves the economics, as the cost of enzymes constitutes a major part of the total cost. Lignocellulosics are abundant sources of carbohydrate, continually replenished by photosynthetic reduction of carbon dioxide by sunlight energy. Lignocelluloses are complex polymers consisting of cellulosic fibrous bundles encased in polymer of matrix of hemicellulose and lignin. Whether lignocelluloses could support cellulase production by Penicillium sp. was tested. Of all these lignocelluloses supplemented in the Dox medium, sawdust secretion maximal protein content along with highest titers of cellulolytic enzymes (Table 4). Growth of Penicillium sp. on medium with saw dust yielded biomass considerably high but lower than that obtained on wheat bran. However, wheat bran ranked the second in order in supporting cellulase production and secretion of extracellular protein content. Four species of Cyathus produced biomass of 4.3-4.5 g and a complete cellulase system on paddy husks (Alka-Gupta et al. 1999). Of the cellulosic materials tested, rice straw supplemented medium production of cellulase activity by Penicillium sp. (Picart et al. 2007). Hafiz Iqbal et al. (2010) investigated the potential of a filamentous fungus, Trichoderma harzianum for hyperproduction of the most demanded industrial enzyme carboxymethyl cellulase using cheap and easily available agro-industrial residue wheat straw as growth supporting substrate under still culture solid state fermentation technique. According to the study of Alam et al. (2009) growth of Trichoderma harzianum T2008 on empty fruit bunches under SSF exhibited maximum FPase activity $(8.2 \mathrm{IU} / \mathrm{g})$ at $32{ }^{\circ} \mathrm{C}$ after 4 days of incubation in Erlenmeyer flask.

Mrudula and Murugammal (2011) reported maximum cellulase production by Aspergillus niger using coir waste as substrate. Utilization of $1 \mathrm{~g}$ of rice straw by successive cultivation of Aspergillus ustus, Trichoderma sp., Botrytis sp. and Sporotrichum sp. on rice straw and wheat bran in solid state fermentation gave production of $14 \mathrm{U}$ of FPA, $22 \mathrm{U}$ of CMCase and $48 \mathrm{U}$ of $\beta$-glucosidase per gram of dry solids utilized in solid state fermentation (Duemas et al. 1995). Growth of Chaetomium globosum on oil palm empty fruit bunch fiber yielded titer of FPase $(2.5 \mathrm{U} / \mathrm{ml})$, CMCase $(59 \mathrm{U} / \mathrm{ml})$ and $\beta$-glucosidase $(12 \mathrm{U} / \mathrm{ml})$. Solidstate fermentation of coconut coir pith by $T$. viridae for 7 days produced Fpfase $4.7 \mathrm{U}$, CMCase of $12 \mathrm{U}$ and P-glucosidase of $1.8 \mathrm{U}$ per gram of dry solid (Muniswaran and Charyulu 1994). Growth of A. niger, Pencillium citrinum, $P$. chysogenum on modified Czapek Dox medium supplemented with wheat bran produced maximum extracellular Fpase, CMCase and $\beta$-glucosidase activity (EIShayeb et al. 1992). 
Temperature highly influences the growth and enzymatic activities of organism. Many researchers have reported different temperatures for maximum cellulase production either in flask or in fermenter studies using Aspergillus sp. and Trichoderma sp. suggesting that the optimal temperature for cellulase production also depends on the strain variation of the microorganism (Krishna 1999; $\mathrm{Lu}$ et al. 2003). The growth, extracellular protein content and cellulases production by Penicillium sp. grown at three different temperatures was monitored and are presented in Table 5. Among three tested temperatures, $30{ }^{\circ} \mathrm{C}$ is the better choice for cellulase activity along with growth and extracellular protein content. Fungal strain $P$. sajor-caju yielded highest activities of Endo- $\beta$-1, 4-glucanase, Exo- $\beta$ 1,4 -glucanase and $\beta$-glucosidase to the tune of 18.98 , 13.63 and 18.54 Units ( $\mu \mathrm{mol}$ of glucose released $/ \mathrm{min} / \mathrm{g}$ substrate), respectively, at $25{ }^{\circ} \mathrm{C}$ (Pandit and Maheshwari 2012). Optimal temperature at $30{ }^{\circ} \mathrm{C}$ was observed for cultivation of Aspergillus niger on coir waste for production of cellulase (Mrudula and Murugammal 2011). Highest $\beta$-glucosidase activity by $T$. viridae in maize cobs medium incubated at $28^{\circ} \mathrm{C}$ (Ye and Fields 1989) occurred. $T$ viridae produced the highest level of cellulase on dried apple pomace under solid state fermentation incubated at $30{ }^{\circ} \mathrm{C}$ for 7-days (Bhalla and Joshi 1993). The optimum temperature for the production of CMCase by Aspergillus sp. was $37^{\circ} \mathrm{C}$ (Asquieri and Park 1992; Kathiresan and Manivannan 2006; Devanathan et al. 2007). The increase in the culture temperature of thermophilic cultures of Allesheria terretris from 40 to $48{ }^{\circ} \mathrm{C}$ resulted in high cellulase production (Kvesitadze et al. 1986). High CM-cellulase and $\beta$-glucosidase activities were reported with $T$.

Table 4 Cellulase production on lignocelluloses by Penicillium sp.

\begin{tabular}{|c|c|c|c|c|c|}
\hline \multirow[t]{2}{*}{ Source } & \multirow{2}{*}{$\begin{array}{l}\text { Dry weight of mycelial } \\
\text { mat (mg/flask) }\end{array}$} & \multirow{2}{*}{$\begin{array}{l}\text { Protein content } \\
(\mathrm{mg} / \mathrm{ml})\end{array}$} & \multicolumn{3}{|l|}{ Cellulase } \\
\hline & & & ${ }^{\mathrm{a}} \mathrm{FPase}(\mathrm{FPU} / \mathrm{ml})$ & ${ }^{\mathrm{b}} \mathrm{CMCase}(\mathrm{U} / \mathrm{ml})$ & ${ }^{\mathrm{c}} \mathrm{B}$-glucosidase $(\mathrm{U} / \mathrm{ml})$ \\
\hline Saw-dust & 573 & 2.34 & 6.59 & 23.05 & 5.03 \\
\hline Rice-straw & 341 & 1.36 & 4.47 & 13.88 & 3.47 \\
\hline Wheat bran & 605 & 1.72 & 4.94 & 16.70 & 4.37 \\
\hline Paper & 315 & 1.42 & 0.59 & 9.90 & 2.85 \\
\hline control & 378 & 2.28 & 5.99 & 11.99 & 1.98 \\
\hline
\end{tabular}

Values represented in the table are averages of results of two experiments

-nd- not detected

${ }^{\text {a }}$ Filter paperase (FPase) is expressed in terms of filter paper units. One unit is the amount of enzyme in the culture filtrate releasing $\mu$ mol of reducing sugar from filter paper per min

${ }^{\mathrm{b}}$ Carboxymethyl cellulase (CMCase) is expressed in terms of units. One unit is the amount of enzyme releasing $1 \mu$ mol of reducing sugar from carboxymethyl cellulose per min

${ }^{c}$ One unit of $\beta$-glucosidase activity is defined as the amount of enzyme liberating $1 \mu$ mol of $p$-nitrophenol per min

Table 5 Effect of temperature on the production of cellulase by Penicillium sp.

\begin{tabular}{|c|c|c|c|c|c|}
\hline \multirow[t]{2}{*}{ Temperature $\mathrm{E}\left({ }^{\circ} \mathrm{C}\right)$} & \multirow{2}{*}{$\begin{array}{l}\text { Dry weight of mycelial } \\
\text { mat (mg/flask) }\end{array}$} & \multirow{2}{*}{$\begin{array}{l}\text { Protein content } \\
(\mathrm{mg} / \mathrm{ml})\end{array}$} & \multicolumn{3}{|l|}{ Cellulase } \\
\hline & & & ${ }^{\mathrm{a}} \mathrm{FPase}(\mathrm{FPU} / \mathrm{ml})$ & ${ }^{\mathrm{b}} \mathrm{CMCase}(\mathrm{U} / \mathrm{ml})$ & ${ }^{\mathrm{c}} \mathrm{B}$-glucosidase $(\mathrm{U} / \mathrm{ml})$ \\
\hline $25^{\circ} \mathrm{C}$ & 293 & 1.02 & -nd- & 4.56 & 0.62 \\
\hline $30{ }^{\circ} \mathrm{C}$ & 457 & 2.12 & 2.03 & 9.83 & 1.04 \\
\hline $37^{\circ} \mathrm{C}$ & 457 & 2.12 & 1.62 & 6.24 & 0.99 \\
\hline
\end{tabular}

Values represented in the table are averages of results of two experiments -nd- not detected

${ }^{a}$ Filter paperase (FPase) is expressed in terms of filter paper units. One unit is the amount of enzyme in the culture filtrate releasing $\mu$ mol of reducing sugar from filter paper per min

${ }^{\mathrm{b}}$ Carboxymethyl cellulase (CMCase) is expressed in terms of units. One unit is the amount of enzyme releasing $1 \mu \mathrm{mol}$ of reducing sugar from carboxymethyl cellulose per min

${ }^{c}$ One unit of $\beta$-glucosidase activity is defined as the amount of enzyme liberating $1 \mu$ mol of $p$-nitrophenol per min 
viridae, $T$ harzianum and Gliocladium virens in basal medium incubated at $30{ }^{\circ} \mathrm{C}$ (Gomes et al. 1989). Maximum CM-cellulase and filter paper activity were observed with Ulocladium chartarum in basal medium incubated at $30{ }^{\circ} \mathrm{C}$ among a range of temperature from 5 to $45^{\circ} \mathrm{C}$ used in the study (Sallam et al. 1988). Similarly, optimum temperature was found to be $30{ }^{\circ} \mathrm{C}$ for cellulase production by Penicillium sp. in the present study. Ali et al. (1991) reported maximum yield of cellulase by Aspergillus niger Z10 strain and A. terreus at $40{ }^{\circ} \mathrm{C}$, respectively in SSF.

Among physical parameters, $\mathrm{pH}$ of the growth medium plays an important role by inducing morphological changes in microbes and in enzyme secretion. The $\mathrm{pH}$ change observed during the growth of microbes also affects product stability in the medium. The optimal $\mathrm{pH}$ varies with different microorganisms and enzymes. The effect of initial $\mathrm{pH}$ on cellulase production by Penicillium sp. in Czapek-Dox medium with $0.5 \%$ (w/v) of cellulose powder was assessed. The results are represented in Table 6. Penicillium sp. produced maximum growth and secretion of extracellular protein when cultured at $\mathrm{pH}-5$. This was reflected by yields of fungal mat ( $457 \mathrm{mg} / \mathrm{flask}$ ) and $(2.12 \mathrm{mg} / \mathrm{ml})$ of extracellular protein in the culture filtrate at the end of 7 th-days incubation. High activities of FPase $(2.03 \mathrm{U} / \mathrm{ml})$, CMCase $(9.839 \mathrm{U} / \mathrm{ml})$ and $\beta$-glucosidase $(1.04 \mathrm{U} / \mathrm{ml})$ were observed. Low activities of the above described enzymes were observed in the cultured flasks whose initial $\mathrm{pH}$ of the medium was set to $\mathrm{pH}-6.0$ and $\mathrm{pH}-7.0$, but extracellular protein content was little high in $\mathrm{pH}-7.0$ than $\mathrm{pH}-6.0$. Very low vegetative growth of $75 \mathrm{mg} / \mathrm{flask}$ and $0.2 \mathrm{mg} / \mathrm{ml}$ of extracellular protein content and no individual cellulolytic enzyme activities were recorded when the culture was grown on the medium with initial pH-3.0. No FPase, but $1.02 \mathrm{U} / \mathrm{ml}$ of endoglucanase and $0.18 \mathrm{U} / \mathrm{ml}$ of $\beta$-glucosidase was observed in the culture whose initial $\mathrm{pH}$ was set to $\mathrm{pH}-4.0$. Only CMCase with measurable $1.153 \mathrm{U} / \mathrm{ml}$ was detected in the culture filtrate of the culture grown at $\mathrm{pH}-8.0$. It was clear from the results that $\mathrm{pH}-5.0$ was found to be maximal for the production of biomass and cellulase complex by Penicillium sp.

The highest activities of Endo- $\beta$-1, 4-glucanase (17.65 U/g), Exo- $\beta$-1, 4-glucanase (13.49 U/g) and $\beta$-glucosidase $(14.62 \mathrm{U} / \mathrm{g}$ ) were obtained at $\mathrm{pH}$ of 5 (Pandit and Maheshwari 2012). The maximum cellulase activity was achieved when Trichoderma viride strains were cultivated in medium set to a range of $\mathrm{pH} 5-6$; as $\mathrm{pH}$ increased up to 5.5 , the hyper activities of exoglucanase $(2.16 \mathrm{U} / \mathrm{ml})$, endoglucanase $(1.94 \mathrm{U} / \mathrm{ml})$ and $\beta$-glucosidase $(1.71 \mathrm{U} / \mathrm{ml})$ were observed (Gautam et al. 2010). Similarly, Maheswari et al. (1993) made an observation that acidic pH-5.5 was found to be optimal for maximal cellulase production. The initial $\mathrm{pH}$ of the culture medium had marked effect on cellulase production by the different organisms. The production of cellulolytic enzymes by Sacchobolus saccoboloides (Magnelli et al. 1996), Nectria cataliensis (Pardo and Forchiassin 1998; Romero et al. 1999) was maximal at the initial $\mathrm{pH}$ of growth medium of 6.5. Higher level cellulolytic activity in respect of Coriolus hirsitus and Coriolus versicolor grown at $\mathrm{pH}-6.5$ to 7.5 than at $\mathrm{pH}$ 3.0-4.0 was correlated to their higher growth (Dudehenko et al. 1988). The activity of the culture grown at $\mathrm{pH}-5.0$ was fairly stable and optimum compared to other $\mathrm{pH}$ value with Fusarium solani (Bisen et al. 1982). The yield of cellulase by Trichoderma harzianum was improved at $\mathrm{pH}$ 5.0 (Rousses and Raimbault 1982). In the present study, pH was not controlled in the medium during the course of experiment. The yields of enzyme production might have

Table 6 Effect of $\mathrm{pH}$ on the production of cellulase by Penicillium sp.

\begin{tabular}{|c|c|c|c|c|c|}
\hline \multirow[t]{2}{*}{ Initial $\mathrm{pH}$} & \multirow{2}{*}{$\begin{array}{l}\text { Dry weight of mycelial } \\
\text { mat (mg/flask) }\end{array}$} & \multirow{2}{*}{$\begin{array}{l}\text { Protein content } \\
(\mathrm{mg} / \mathrm{ml})\end{array}$} & \multicolumn{3}{|l|}{ Cellulase } \\
\hline & & & ${ }^{\mathrm{a}} \mathrm{FPase}(\mathrm{FPU} / \mathrm{ml})$ & ${ }^{\mathrm{b}} \mathrm{CMCase}(\mathrm{U} / \mathrm{ml})$ & ${ }^{\mathrm{c}} \mathrm{B}$-glucosidase $(\mathrm{U} / \mathrm{ml})$ \\
\hline 3 & 075 & 0.2 & -nd- & -nd- & -nd- \\
\hline 4 & 217 & 1.95 & -nd- & 1.02 & 0.18 \\
\hline 5 & 457 & 1.92 & 2.03 & 9.83 & 1.04 \\
\hline 6 & 450 & 1.52 & 1.14 & 6.53 & 0.67 \\
\hline 7 & 400 & 1.60 & 0.94 & 4.21 & 0.21 \\
\hline 8 & 206 & 1.16 & 1.15 & -nd- & -nd- \\
\hline
\end{tabular}

Values represented in the table are averages of results of two experiments

-nd- not detected

${ }^{\text {a }}$ Filter paperase (FPase) is expressed in terms of filter paper units. One unit is the amount of enzyme in the culture filtrate releasing 11.1 mol of reducing sugar from filter paper per min

${ }^{\mathrm{b}}$ Carboxymethyl cellulase (CMCase) is expressed in terms of units. One unit is the amount of enzyme releasing $1 \mu$ mol of reducing sugar from carboxymethyl cellulose per min

${ }^{c}$ One unit of 13 -glucosidase activity is defined as the amount of enzyme liberating $1 \mu$ mol of $p$-nitrophenol per min 
Table 7 Effect of supplementation of surfactants source on cellulase production by Penicillium sp.

\begin{tabular}{|c|c|c|c|c|c|}
\hline \multirow[t]{2}{*}{ Source } & \multirow{2}{*}{$\begin{array}{l}\text { Dry weight of mycelial } \\
\text { mat (mg/flask) }\end{array}$} & \multirow{2}{*}{$\begin{array}{l}\text { Protein content } \\
(\mathrm{mg} / \mathrm{ml})\end{array}$} & \multicolumn{3}{|l|}{ Cellulase } \\
\hline & & & ${ }^{\mathrm{a}} \mathrm{FPase}(\mathrm{FPU} / \mathrm{ml})$ & ${ }^{\mathrm{b}} \mathrm{CMCase}(\mathrm{U} / \mathrm{ml})$ & ${ }^{\mathrm{c}} \mathrm{B}$-glucosidase $(\mathrm{U} / \mathrm{ml})$ \\
\hline SDS & 350 & 1.62 & -nd- & 9.88 & 1.66 \\
\hline SDO & 410 & 1.23 & -nd- & 7.52 & 0.90 \\
\hline TritonX-100 & 514 & 2.01 & 3.08 & 11.99 & 1.99 \\
\hline Tween-80 & 492 & 1.74 & -nd- & 10.25 & 1.04 \\
\hline Tween-20 & 480 & 1.67 & -nd- & 9.88 & 2.84 \\
\hline Control & & & 5.99 & 11.99 & 1.98 \\
\hline
\end{tabular}

Values represented in the table are averages of results of two experiments

$S D O$ sodium deoxycholate

-nd- not detected

a Filter paperase (FPase) is expressed in terms of filter paper units. One unit is the amount of enzyme in the culture filtrate releasing 11.1 mol of reducing sugar from filter paper per min

${ }^{\mathrm{b}}$ Carboxymethyl cellulase (CMCase) is expressed in terms of units. One unit is the amount of enzyme releasing $1 \mu$ mol of reducing sugar from carboxymethyl cellulose per min

c One unit of 13-glucosidase activity is defined as the amount of enzyme liberating $1 \mu$ mol of $p$-nitrophenol per min

been further improved with $\mathrm{pH}$ control during the course of the growth.

The effect of surfactants (sodium dodecyl sulphate, sodium deoxycholate, Triton X-100, Tween-20 and Tween80 ) on the production of cellulase by Penicillium sp. was determined after 7 days of incubation in Table 7. Highest production of dry mass $(514 \mathrm{mg} /$ flask), and extracellular protein content $(2.01 \mathrm{mg} / \mathrm{ml})$ was recovered in the culture filtrate grown on Triton-X100 supplemented medium. The same culture filtrate exhibited maximum activities of FPase (3.088 U/ml), CMCase (11.999 U/ml) and $1.992 \mathrm{U} / \mathrm{ml}$ of glucosidase. No FPase activity was detected in other surfactants used in this study. Low amounts of dry mass in sodium dodecyl sulphate $(350 \mathrm{mg} /$ flask $)$, extracellular protein content in sodium deoxycholate $(1.23 \mathrm{mg} / \mathrm{ml})$ were observed. Only $7.529 \mathrm{U} / \mathrm{ml}$ of CMCase and $0.903 \mathrm{U} / \mathrm{ml}$ of $\beta$-glucosidase activity were recorded in the presence of sodium deoxycholate. Among different non-ionic surfactants (Tween-20, Tween-80, and Triton X-100) and polyethylene glycol (PEG-600), Tween-80 yielded highest titers of exoglucanase, endoglucanase and cellobiase by Nectria cataliensis (Pardo 1996). This similar effect of Tween-80 on production of extracellular protein, in particular, cellulase by other organisms, Trichoderma (Reese and Maguire 1969; Domingues et al. 2000) and thermophile Thermomonospora curvata (Stutzenberger 1987) was observed. According to the study of Domingues et al. (2000), Tween-80 influenced the morphology of Trichoderma reesei Rut $\mathrm{C}-30$ as well as the enzyme production. The stimulatory effect of surfactants may be a consequence of its action on cell membranes causing increase in permeability by promoting the release of cell-bound enzymes (Abdel-Fatah et al. 2012). On the other hand, Triton X-100 appeared to be the best surfactant for the production of cellulase in the present study.

Growth of Penicillium sp. on optimized medium (cellulose $0.5 \%$, lactose $0.5 \%$, sawdust $0.5 \%$, yeast extract $0.2 \%$, and Triton-X $1000.015 \%$ at $\mathrm{pH} 5.0$, temperature $30{ }^{\circ} \mathrm{C}$ ) in submerged fermentation in the present study yielded the production of Fpase, CMCase and $\beta$-glucosidase to the extent of $8.7,25$ and $9.2 \mathrm{U} / \mathrm{ml}$, respectively, which was 9.2, 5.9 and 43.8-folds higher than titers of the respective enzymes obtained on unoptimized medium with the same culture. The extracellular protein content $(4.5 \mathrm{mg} /$ $\mathrm{ml})$ and biomass (520 mg/flask) was also increased under optimal conditions over unoptimized conditions. Similarly, optimization of medium components resulted in enhancement in production of cellulose enzymes by Penicillium echinulatum by $20-80 \%$ over unoptimised medium (dos Reis et al. 2015) It is clear from the results of the present study that Penicillium sp. secreted cellulase with high $\beta$ glucosidase activity in $\mathrm{SmF}$ and the ratio of $\beta$-glucosidase to Fpase of Penicillium sp. is greater than one and will be useful in saccharification process of lignocellulosic biomass for biofuel production.

\section{Compliance with ethical standards}

Conflict of interest Authors declare that there are no conflicts of interests among the authors about the publication of the manuscript.

Open Access This article is distributed under the terms of the Creative Commons Attribution 4.0 International License (http:// creativecommons.org/licenses/by/4.0/), which permits unrestricted use, distribution, and reproduction in any medium, provided you give appropriate credit to the original author(s) and the source, provide a link to the Creative Commons license, and indicate if changes were made. 


\section{References}

Abdel-Fatah Hassan MM, Elshafei AM, Haroun BM, Atta HM, Othman AM (2012) Physiological studies on carboxymethyl cellulase formation by Aspergillus terreus DSM 826. Brz J Microbiol 43(1):1-11

Adrio JL, Demain AL (2014) Microbial enzymes: tools for biotechnological processes. Biomolecules 4:117-139

Alam MDZ, Mamun AA, Qudsieh IY, Muyibi SA, Salleh HM, Omer NM (2009) Solid state bioconversion of oil palm empty fruit bunches for cellulase enzyme production using a rotary drum bioreactor. Biochem Eng J 46:61-64

Ali S, Sayed A, Sarker RI, Alam R (1991) Factors affecting cellulase production by Aspergillus terreus using water hyacinth. World $\mathrm{J}$ Microbiol Biotechnol 7(1):62-66

Alka-Gupta MuraliGopal, Kuhad RC (1999) Production of cellulase and degradation of cellulosic substrate by Cyathus sp. Agri Sci Dig 19:7-11

Allen AL, Andreotti RF (1982) Cellulase production in continuous and fed cultures by Trichoderma reesei MCG 80. Biotechnol Bioeng Symp 12:451-459

Ashfaq A, Khatoon A (2013) Prevention of Environmental Degradation by means of solid waste management. J Ind Pollut Control 29:57-60

Asquieri ER, Park YK (1992) Production of extracellular cellulases from the thermostable Aspergillus sp. Rev Microbiol 23:183-188

Bhalla TC, Joshi M (1993) Production of cellulase and xylanase by Trichoderma viridae and Aspergillus sp. on apple pomace. Indian J Microbiol 33:253-290

Bhat MK (2000) Cellulases and related enzymes in biotechnology. Biotechnol Adv 18:355-383

Bhat MK, Bhat S (1997) Cellulose-degrading enzymes and their potential applications. Biotechnol Adv 15:583-620

Bilai TI, Shabunina TI, Slyusarenko TP (1985) Effect of cultivation conditions of protein formation by Chrysosporium sp. and Thielavia sp. micromycetes. Microbiol Zh 47:92-94

Bisen PS, Gosh K, Agrawal GP (1982) Introduction and inhibition of cellulase complex in Fusarium solani. Biochem Physiol Pflanz 177:593-599

Coral G, Arikan B, Unaldi MN, Guvenmes H (2002) Some properties of crude carboxymethyl cellulase of Aspergillus niger Z10 wildtype strain. Turk J Biol 26:209-213

Devanathan G, Shanmugan A, Balasubramanian T, Manivannan S (2007) Cellulase production by Aspergillus niger isolated from coastal mangrove debris. Trends Appl Sci Res 2:23-27

Domingues FC, Quieroz JA, Cabral JMS, Fanseca LP (2000) The influence of culture conditions on mycelial structure and cellulase production by Trichoderma reeseirut C-30. Enzym Microb Technol 26:394-401

dos Reis L, Ritter CET, Fontana RC, Camassola M, Dillon AJP (2015) Statistical optimization of mineral salt and urea concentration for cellulase and xylanase production by Penicillium echinulatum in submerged fermentation. Braz J Chem Eng 32:13-22

Dudehenko LG, Semichaevsky VD, Mcinichuk GG (1988) Effect of medium $\mathrm{pH}$ on extracellular enzyme production by Wood destroying fungi. Mikol Fitopatol 22:135-141

Duemas R, Tengerdy RP, Gutieroez-Correa M (1995) Cellulase production by mixed fungi in solid substrate fermentation of bagasse. World J Microbiol Biotechnol 11:333-337

EI-Shayeb NMA, Mabrouk SS, Ismail SA, Abdel-Fattah AF (1992) Production of fungal enzymes with special reference to $\beta$ glucosidases. Zhl Microbiol 147:563-568

Farid MA, El-Shaheed KY (1993) Cellulase production on high levels of cellulose and corn sleep liquor. Zhl Mikrobiol 148:277-283
Gadgil NJ, Daginawala HF, Chakarabarti T, Khanna P (1995) Enhanced cellulase production by a mutant of Trichderma reesei. Enzym Microb Technol 17:942-946

Ganguly R, Mukherjee SK (1995) Effects of different pure and complex carbon and nitrogen sources on production of cellulases by an isolated strain Penicillium purpurogenum. J Microbiol Biotech 10:47-58

Gautam SP, Bundela PS, Pandey AK, Awasthi MK, Sarsaiya S (2010) Optimization of the medium for the production of cellulase by the Trichoderma viride using submerged fermentation. Int $\mathrm{J}$ Environ Sci 1(4):330-333

Ghosh TK (1987) Measurement of cellulase activities. Pure Appl Chem 59:257-268

Gomes I, Gomes J, Gomes DJ, Steiner W (2000) Simultaneous production of high activities of thermostable endoglucanase and $\beta$-glucosidase by the wild thermophilic fungus Thermoascus aurantiacus. Appl Microbiol Biotechnol 53:461-468

Gomes J, Gomes I, Estearbauer H, Kreiner W, Steiner W (1989) Production of cellulases by a wild strain of Gliocladium virens. Optimisation of the fermentation medium and partial characterisation of the enzymes. Appl Microbiol Biotechnol 31:601-608

Guptha U, Roma R, Phutel RP, Guptha U, Karla R (1996) Factors affecting cellulose production in Volvariella, the straw mushroom. Mushroom Res 5(1):29-32

Gusakov AV, Sinitsyn AP (2012) Cellulases from Penicillium species for producing fuels from biomass. Biofuels 3(4):463-477

Han L, Feng J, Zhu C, Zhang X (2009) Optimizing cellulase production of Penicillium waksmanii F10-2 with response surface methodology. Afr J Biotechnol 8:3879-3886

Hayward T, Hamilton J, Tholudur A, McMillan J (2000) Improvements in titer, productivity, and yield using solka-floc for cellulase production. Appl Biochem Biotechnol 84(1):859-874

Herr D (1979) Secretion of cellulases and $\beta$-glucosides by Trichoderma viridae TTCC 1433 in submerged cultures on different substrates. Biotechnol Bioeng 21:1361-1363

Hinds GR (2015) High-Solids Anaerobic Digestion of the Organic Fraction of Municipal Solid Waste State of the Art, Outlook in Florida, and Enhancing Methane Yields from Lignocellulosic Wastes. Graduate thesis, University of South Florida

Hoshino E, Shiroishi M, Amano Y, Nomura M, kanda T (1997) Synergistic action of exo-type cellulases in the hydrolysis of cellulose with different crystallite. J Ferment Bioeng 484:300-306

Iqbal H, Javed MM, Khan TS, Siddiq Z (2010) Cotton Saccharifying Activity of Cellulases Produced by Co-culture of Aspergillus niger and Trichoderma viride. Res J Agri Biol Sci 1(3):241-245

Iqbal HMN, Ahmed I, Zia MA, Irfan M (2011) Purification and characterization of the kinetic parameters of cellulase produced from wheat straw by Trichoderma viride under SSF and its detergent compatibility. Adv Biosci Biotechnol 2(3):149-156

Jeihanipour A, Bashiri R (2015) Perspective of Biofuels from Wastes. In: Karimi K (ed) Lignocellulose-Based Bioproducts, Biofuel and Biorefinery Technologies 1, doi:10.1007/978-3-319-14033-9_2

Jha K, Khare SK, Gandhi AP (1995) Solid state fermentation of soyhull for the production of cellulase. Bioresour Technol 54:321-322

Jorgensen H, Mørkeberg A, Krogh KBR, Olsson L (2005) Production of cellulases and hemicellulases by three Penicillium species: effect of substrate and evaluation of cellulase adsorption by capillary electrophoresis. Enzym Microb Technol 36(1):42-48

Kathiresan K, Manivannan S (2006) Cellulase production by Penicillium fellutanum isolated from coastal mangrove rhizosphere soil. Res J Microbiol 1(5):438-442

Koneswaran G, Nierenberg D (2008) Global farm animal production and global warming: impacting and mitigating climate change. Environ Health Perspect 116(5):578-582 
Koomnok C (2005) Selection of cellulase producing thermophilic fungi. 31st Congress on Science and Technology of Thailand

Krishna C (1999) Production of bacterial cellulases by solid state bioprocessing of banana wastes. Bioresour Technol 69(3):231-239

Kuhad RC, Guptha R, Singh A (2011) Microbial cellulases and their industrial applications. Enzym Res 2011:1-10

Kvesitadze G, Gogilashvidi L, Svaondize p, Buachidaze T, Chirgadze L, Lizharadze D (1986) Exogeneous celluloses of thermophilic micromycetes. II. Thermostability of enzyme preparations. Acta Biotechnol 6:361-367

Lee SY, Park JH, Jang SH, Nielsen LK, Kim J, Jung JS (2008) Fermentative butanol production by Clostridia. Biotechnol Bioeng 101(2):209-228

Lee BH, Kim BK, Lee YJ, Chung CH, Lee JW (2010) Industrial scale of optimization for the production of carboxymethylcellulase from rice bran by a marine bacterium, Bacillus subtilis subsp. subtilis A-53. Enzym Microb Technol 46(1):38-42

Li YL, Li H, Li AN, Li DC (2009) Cloning of a gene encoding thermostable cellobiohydrolase from the thermophilic fungus Chaetomium thermophilum and its expression in Pichia pastoris. J Appl Microbiol 106:1867-1875

Lowry OM, Rosebrough NJ, Farr AL, Randall RJ (1951) Protein measurement with Folin phenol reagent. J Biol Chem 193:265-275

Lu W, Li D, Wu Y (2003) Influence of water activity and temperature on xylanase biosynthesis in pilot-scale solid-state fermentation by Aspergillus sulphureus. Enzym Microb Technol 32(2):305-311

Lytle CLG (2016) When the mermaids cry: The Great Plastic Tide. http://coastalcare.org/2009/11/plastic-pollution/. Accessed 8 Aug 2016

Magnelli P, Ramos AM, Forchiasin FM (1996) Factors influencing cellulase production by Saccobollus saccoboloides. Mycologia $88: 249-255$

Maheswari DK, Jahan H, Paul J, Varma A (1993) Wheat straw a potential substrate for cellulase production using Trichoderma reesei. World J Microbiol Biotechnol 9:120-121

Mandels M, Weber J (1969) Cellulases and its application. In: Gould RF (ed) Advances in Chemistry Series, vol 95. American Chemical Society, Washington, pp 391-414

Miller GL (1959) Use of dinitrosalicylic acid reagent for determination of reducing sugars. Anal Chem 31:426-429

Mrudula S, Murugammal R (2011) Production of cellulase by Aspergillus niger under submerged and solid state fermentation using coir waste as a substrate. Braz J Microbiol 42:1119-1127

Muniswaran PKA, Charyulu NCLN (1994) Solid substrate fermentation of coconut coir pitch for cellulase production. Enzym Microb Technol 16:436-440

Muthuvelayudham R, Viruthagiri T (2006) Fermentative production and kinetics of cellulase protein on Trichoderma reesei using sugarcane bagasse and rice straw. Afr $\mathrm{J}$ Biotechnol 5(20):1873-1881

Narasimha G, Babu GVAK, Rajasekhar Reddy B (1999) Effect of effluents of cotton ginning industry on physico-chemical and biological properties of soil. J Environ Biol 20(3):235-239

Nigam P, Prabhu KA (1991) Effect of cultural factors on cellulase biosynthesis in submerged bagasse fermentation by basidiomycetes cultures. J Basic Microbiol 31:286-292

Pandit NP, Maheshwari SK (2012) Optimization of cellulase enzyme production from sugarcane pressmud using oyster mushroompleurotus sajor-caju by solid state fermentation. J Bioremed Biodegrad 3:140. doi:10.4172/2155-6199.1000140

Pardo AG (1996) Effect of surfactants on cellulase production by Nectria catalinensis. Curr Microbiol 33:275-278
Pardo AG, Forchiassin F (1998) Influence of different cultural conditions on cellulase production by Nectria catalensis. Revista-Argentina-de-Microbiologia 30:20-29

Patil SC, Patil BG, Bastande KB, Gokhale DV (1995) Supplementation with skim milk enhances the cellulolytic activity of fungi. Biotechnol Lett 17:631-634

Penttila M, Limon C, Nevalainen H (2004) Molecular biology of Trichoderma and biotechnological applications, Handbook of Fungal Biotechnology. Marcel Dekker, New York

Peterson R, Nevalainen H (2012) Trichoderma reesei RUT-C30 thirty years of strain improvement. Microbiology 158(1):58-68

Picart P, Diaz P, Pastor FIJ (2007) Cellulases from two Penicillium sp. strains isolated from subtropical forest soil: production and characterization. Lett Appl Microbiol 45:108-113

Polyanna NH, Porto TS, Moreira KA, Pinto GAS, Cristina MSM, Ana LFP (2011) Cellulase production by Aspergillus japonicus URM5620 using waste from castor bean (Ricinus communis L.) under solid state fermentation. Appl Biochem Biotechnol 165:1057-1067

Prasanna HN (2003) Cellulase production by Penicilium sp. M.Phill thesis submitted to Sri Krishnadevaraya University, Anantapur, A.P. India

Reese ET, Maguire A (1969) Surfactants as stimulants of enzyme production by microorganisms. Appl Microbiol 17:242-245

Ritter CET, Camassola M, Zampieri D, Silveira MM, Dillon AJP (2013) Cellulase and xylanase production by Penicillium echinulatum in submerged media containing cellulose amended with sorbitol. Enzym Res. doi:10.1155/2013/240219

Romero MB, Aguado J, Gonzalez L, Ladero M (1999) Cellulase production by Neurospora crassa on wheat straw. Enzym Microb Technol 25:244-250

Rousses S, Raimbault M (1982) Hydrolysis of cellulose by fungi. II Cellulase production by Trichoderma harzianum in liquid medium fermentation. Ann Microbiol (Paris) 133B:465-474

Ruijter GG, Visser J (1997) Carbon repression in Aspergilli. FEMS Microbiol Lett 151:103-114

Sallam LAR, El-Rafai AMH, El-Sayed SM (1988) Cellulase production by halophylic fungi. I. Screening experiments and salt relations. Zhl Mikrobiol 143:599-604

Sanil S, Baer ZC, Pazhamalai A, Gunbas G, Grippo A, Blanch HW, Clark DS, Toste FD (2015) Production of an acetone-butanolethanol mixture from Clostridium acetobutylicum and its conversion to high-value biofuels. Nat Protocol 10(3):528-537

Singhania RR, Sukumaran RK, Pillai A, Prema P, Szakacs G, Pandey A (2006) Solid state fermentation of lignocellulosic substrates for cellulose production by Trichoderma reesei NRRL 11460 . Indian J Biotechnol 5:332-336

Singhvi MS, Adsul MG, Gokhale DV (2011) Comparative production of cellulases by mutants of Penicillium janthinellum NCIM 1171 and its application in hydrolysis of Avicel and cellulose. Bioresour Technol 102(11):6569-6572

Sternberg D, Mandels GD (1979) Induction of cellulolytic enzymes in Trichoderma ressei by sophorose. J Bacteriol 139:765-769

Stutzenberger FJ (1987) Component-specific simulation of cellulose secretion in Thermo monosporacurvata by the surfactant Tween80. I Appl Bacteriol 63:239-244

Sun X, Liu Z, Zheng K, Song X, Qu Y (2008) The composition of basal and induced cellulase systems in Penicillium decumbens under induction or repression conditions. Enzym Microb Technol 42(7):560-567

Tuo H (2013) Energy and exergy-based working fluid selection for organic Rankine cycle recovering waste heat from high temperature solid oxide fuel cell and gas turbine hybrid systems. Int $\mathbf{J}$ Energy Res 37(14):1831-1841

Van Wyk JPH (2001) Biotechnology and utilization of waste as a resource for bioproduct development. TIB Tech 19:172-177 
Yano S, Ozaki H, Matsuo S, Ito M, Wakayama M, Takagi K (2012) Production, purification and characterization of D-aspartate oxidase from the fungus Trichoderma harzianum SKW-36. Adv Biosci Biotechnol 3(1):7-13

Ye G, Fields ML (1989) Cellulolytic enzyme production by three fungi grown in a ground corn cob medium. J Food Prot $52: 248-251$
Zhao C, Ma Z, Shao Q, Li B, Ye J, Peng H (2016) Enzymatic hydrolysis and physiochemical characterization of corn leaf after H-AFEX pretreatment. Energy Fuels. doi:10.1021/acs. energyfuels.5b02817 